\title{
Attitude to Ageing As a Predictor of Subjective Health and Quality of Life Among Older People in Delta State, Nigeria
}

\author{
Bernedeth N. Ezegbe ${ }^{1}$, Godspower O. Oriehi ${ }^{2}$, Victoria I. Okika ${ }^{2}$, Justina I. Ofuebe ${ }^{3}$, Chinyere Loveth Chukwu ${ }^{1}$, \\ Ifeanyi David Emeka ${ }^{4} \&$ Moses O. Ede ${ }^{2}$ \\ ${ }^{1}$ Department of Social Science Education, University of Nigeria, Nsukka, Nigeria \\ ${ }^{2}$ Department of Educational Foundations, University of Nigeria, Nsukka, Nigeria \\ ${ }^{3}$ Department of Human Kinetics and Health Education, University of Nigeria, Nsukka, Nigeria \\ ${ }^{4}$ ONIT College of Education, Mbaukwu, Anambra State, Nigeria \\ Correspondence: Justina I. Ofuebe, Department of Human Kinetics and Health Education, University of Nigeria, \\ Nsukka, P.M.B. 410001, Enugu State, Nigeria. E-mail: justina.ofuebe@unn.edu.ng
}

Received: February 28, 2019 Accepted: April 9, 2019 Online Published: April 14, 2019

doi:10.5539/gjhs.v11n6p1 URL: https://doi.org/10.5539/gjhs.v11n6p1

\begin{abstract}
Objective: The study investigated attitude to ageing as a predictor of subjective health and quality of life among the older people in Ika South Local Government Area, Delta State. Three research questions guided the study.

Method: The population of the study comprised 6,670 older people 3,323 males and 3347 females in Ika South Local Government Area of Delta State. The sample size of the study is 667 older people in Ika South Local Government Area of Delta State. A multi-stage random sampling technique was used to get the sample size for the study. Two stages of selection were used in order to draw the sample for the study. For the first stage, simple sampling technique was used to draw 11 communities out of 22 communities in the study area. In second stage 10\% of the study population was used. The questionnaires were validated by two experts from guidance and counselling and one from measurement and evaluation. Reliability of the instrument was determined using Cronbach Alpha method reliability estimate. Copies of the questionnaire were administered directly to the respondents. Linear regression was used for the data analysis.
\end{abstract}

Results: The finding of the study revealed that older people of Ika South Local Government Area maintains positive attitude to ageing, that attitude to ageing is not a predictor of subjective health among older people of Ika South Local Government Area and attitude to ageing does not significantly predict quality of life among people of Ika South Local Government Area.

Conclusion: Based on the finding of the study, government and professional guidance counsellors should make use of the information generated from the study to organize workshop training for older people on what constitute subjective health quality of life and what constitute positive attitude to ageing.

Keywords: attitude to ageing, subjective health, quality of life, older people

\section{Introduction}

The ageing of world's population is a crucial challenge for the $21^{\text {st }}$ century. Population ageing affects individuals and nations everywhere. Elderly population is increasing in all countries of the world. This is due to several factors which include improvement in public health, increase in life expectancy and changes in living arrangement among the family structures (Olukorede \& Abiodun, 2014). According to the Economic and Social Commission for Asia and the Pacific, the number of older persons (people aged 60 and above) in Asia, as a whole, will increase geometrically from 322 million in 2000 to up to 705 million in 2025. Countries like Japan and Singapore will likely have the oldest population by 2030 (Troisi, 2004). The decline in mortality rates of infant and children under five-year old suggest that more individuals are growing into adulthood. The decline is attributable to more responsiveness to the risk of overpopulation and the impact of population education, leading to decrease in the number of offsprings per couple (Okoye, 2014).

An attitude has been defined as "an evaluative integration of cognitions and affects experienced in relation to an object. Attitudes are evaluative judgments that integrate and summarize these cognitive/affective reactions. These 
evaluative abstractions vary in strength, which in turn has implications for persistence, resistance, and attitude behaviour consistency (Prislin, Shaffer, \& Crowder, 2012). Individual knowledge, observations and experiences help form attitudes (Tsakiris, Hesse, Boy, Haggard, \& Fink, 2006). Attitudes often exist on a continuum ranging from positive to neutral to negative, which can coexist simultaneously. Attitudes are stable integrative judgments, which recapitulate an individual's feelings, thoughts, and memories related to objects or situations (Prislin, Shaffer, \& Crowder, 2012). Attitudes also incorporate complexity, uncertainty or conflict (Wood, 2000), and can change depending on experience, perceived consequences and attitudinal strength (Ajzen \& Fishbein, 2005).

Previous literature recognized that attitudes towards ageing were critical for older adults' adjustment and survival, as they influence whether behaviours are adaptive or maladaptive and strengthen the perception and approach of younger individuals to their own ageing (Crick \& Dodge, 1994). This view is still considered largely true today. Attitudes to ageing have been defined as affective, cognitive and evaluative components of behaviour toward the process of ageing as a personal experience and toward older adults as a group (Hess, 2006). Thus, attitudes to ageing include feelings, knowledge and assessments of one's own ageing and that of others. Attitudes towards ageing give individuals meaning regarding the experience of ageing, reflecting both individual knowledge and experiences, and influencing behavioural choices (Ajzen \& FIshbein, 1977; Bohner \& Dickel, 2012). When disagreement exists between belief and behaviour components of an attitude, an individual may adjust one to match the other, for example adjusting a belief to match behaviour, according to Dissonance-Reduction theory (Festinger, 1957). Consequently, attitudes may guide information processing and help in individual decide what behaviour is appropriate (Bohner \& Dickel, 2012). Attitudes to ageing are generally seen to function implicitly, guiding emotional response, thought patterns and behaviours, often without individuals' being overtly aware of their influence. Attitudes towards ageing are complex and multidimensional, incorporating both positive and negative views about ageing (Laidlaw et al., 2007).

Ageing is defined physically with regards to body posture, hair colour, voice and ability to see and hear, that is body maturation or what is known as biological and physical changes in the individual overtime (Troisi, 2004). Accordingly, Kessler (1997) physically, an individual's body does not change in homogeneous fashion for some parts, it may decline sooner than other. Indisputably, Lloyd-Sherlock (2004) confirms that ageing is characterized by change in skin, tone and muscle firmness. The United States Social Security Act of 1935 held that old age occurred at 65 years of age. This was later increased to 70 in 1979, and by 1986 (Tout, 1989). In Britain, retirement age was 60 for women and 65 for men, while in Denmark and France; it was 67 and 60 respectively (Adesina, 2011). In the less developed world regions, only eight percent of the population is currently over 60 years of age, but it is projected that by 2050 those within this age group would reach 20 percent of the population (United Nations, 2002).

According to Morris (2007), the elderly may have limitations in physical and mental abilities such that they are unable to engage in activities that require exertion of energy for a long time; and this included the regular circular and other jobs that they engaged in. Thus, they are dependent on their children and other relatives for financial, moral and emotional or psychological support as the case may be. Ageing is a process that starts at birth and continues throughout life (Cummings, Kropf, \& De Weaver, 2000). Age is more than simply a measure of chronological years, it is also a social construct and is uniquely personal (Schwanen, Hardill, \& Lucas, 2012). The researchers define ageing as a constant progression from beginning of birth to death which continues all through life but this ranges varies from society to society and individually which contributes to a large degree the level of older people.

Most developed countries have generally accepted the chronological age of 65years as the definition of an older person (WHO, 2015). In addition to chronological age, the age of a person can be defined in many ways, encompassing biological, psychological and socio-cultural processes (Munne, Cohen, \& Sable, 2002). Age can be defined by the social roles one occupies, by a person's level of physical ability, by a subjective assessment of how old one feels, as well as their chronological years (Barrett \& Cantwell, 2007). It is the last stage in the life processes of an individual. It is a stage age group or generation comprising a segment of the oldest members of a population (WHO, 2015). According to Zhou, Zeng, Yang and Wang, (2007), good quality care service and healthy relationships with older adults are necessary, but are unlikely if people's views of older adults are negative. The researchers define older people as individuals in the last period in the living processes of human being with reference to deterioration. Attitudes to ageing involve the subjective perception of ageing, rather than being based on individuals' chronological age and life experiences.

Subjective health is the best single predictor of life satisfaction for the older population since it is more strongly related to life satisfaction than other factors identified by researchers (Gangbe \& Ducharme, 2006). Subjective 
health is a relevant indicator of therapeutic success. This is in line with the conception of health by the World Health Organization, as more than the absence of illness and which implies also subjective ratings of health, mental wellbeing and social relations. Health has been regarded as a priority issue to older people throughout Africa (Help Age International, 2001). Though studies have shown that life expectancy has increased a great deal but this is only good in a situation of good health (Heeks, 2001). Thus, Alberti and Zimmet, (1998) notes that life expectancy has greatly increased in the past 50years yet, to live longer in bad healthy and disability with dependence on others is "an empty prize".

Quality of life (QOL) is another reliable evaluation concept in relation to older people's health and illness. QOL is defined as the combination of an individual's functional health, feelings circumstances (Hooyman \& Kiyak, 2008). According to Susniene and Jurkauskas (2009), quality of life is understood as subjective understanding of well-being, taking into account individual needs and understanding. Quality of life can be defined as satisfaction of a person with current life dimensions in comparison with the pursued or ideal quality of life (Gilgeous, 1998; Juozulynas \& Cemerych, 2005). Health factor is often given a priority in quality of life though the quality of life concept must be understood more widely. However, there is no universally accepted definition of quality of life. World Health Organization observed that quality of life is an individual's perception of their position in life in the context of the culture and value systems in which they live and in relation to their goals, expectations, values and concerns incorporating physical health, psychological state, level of independence, social relations, personal beliefs and their relationship to salient features of the environment. Many factors influence quality of life, i.e. physical, spiritual and health state, independence level, social relationship with the environment and others (Bagdoniene, 2000; Ruzevicius, 2006). Despite projected rapid population ageing in Nigeria, limited attention has been given to attitude towards ageing among the Nigerian people. To this end, the present study aims to determine the attitude to ageing as predictor of subjective health and quality of life among older people in Ika South Local Government Area (L.G.A) of Delta State, Nigeria.Specifically, the study seeks to ascertain:

1) Attitude to ageing among older males and females in Ika South L.G.A.

2) Extent which attitude to ageing predicts subjective health of older people.

3) Extent which attitude to ageing predicts quality of life of older people.

\subsection{Research Questions}

The following research questions will be posed to guide the study.

1) What is the attitude to ageing among people in Ika South L.G.A?

2) To what extent does attitude to ageing predict subjective health among older people in Ika South L.G.A?

3) To what extent does attitude to ageing predict quality of life among older people?

\subsection{Hypothesis}

H01: Attitude to ageing is not a significant predictor of quality of life among older people.

H02: Attitude to ageing is not a significant predictor of subjective health among older people.

\section{Research Method}

The researchers used cross-sectional survey design. This approach helped the researchers to permits investigation on a sample of an entire population with the intention of making generalization of the findings on the entire population which is elderly people and to establish relationship between the variables under investigation. The choice of this design is based on the fact that the researcher is interested in ascertaining whether attitudes to ageing is a predictor of subjective health and quality of life among the older people in Ika South Local Government Area(L.G.A.) Delta State. This study was conducted in line with the research ethics of the American Psychological Association and in accordance with the WMA Helsinki Declaration.

The study covered Ika South Local Government Area of Delta State, Nigeria. Its headquarters is in the town of Agbor. The Ika speaking people are found within the North West of Delta State. The occupation of the inhabitants in the study area includes; farming, business, and civil service. The population of the study comprised all the older people in Ika South Local Government Area of Delta has a population 6,670 (3,323 males and 3,347 females). The population of the study is made up of elderly people in this study area.

The sample for the study consists of 667 elderly people ( 250 males and 417 females). A multi-stage random sampling technique was used to get the sample size for the study. Thus, two stages, of selections were used in order to draw the sample for the study. For the first stage, simple sampling technique was used to draw 11 communities out of 22 communities in the study area. In the second stage, $10 \%$ of the study population was used. Respondents 
completed informed consent form.

The data collection instruments were Attitudes to Ageing Questionnaire (AAQ), Subjective Health Questionnaire (SHQ) and Older People Quality of Life Questionnaire (OPQOL). The Attitudes to Ageing Questionnaire (AAQ) is a 24-items questionnaire adapted from Shenkin, Watson, Laidlaw, Starr, and Deary (2014). The modified version of the instrument has two sections, A and B. Section A elicited demographic information of the respondents. Section B contained information on attitude to ageing. The AAQ has a three point Likert scale of Strongly Disagree $=\mathrm{SD}$, Neither Agree nor Disagree $=\mathrm{NAD}$, and Strongly Agree (SA), weighted at 3, 2 and 1 respectively. The questionnaire has three clusters. Cluster A deals with psychological loss. Cluster B focus on physical change. Cluster $\mathrm{C}$ centers on psychological growth. Each cluster has eight items.

Subjective Health Questionnaire (SHQ) is a 36 items questionnaire adapted from researchers (Hays \& Shapiro, 1992; Stwar, et al., 1992). The modified version of the instrument has two sections, A and B. Section A contains the information of the respondents. Section B contains information on subjective health. The SHQ has eight clusters. Cluster A which measures physical functioning has a five point Likert scale namely, Excellent (E), Very good (VG), Good (G), Fair (F), and weight at 5, 4, 3, 2, 1. Cluster B measures role limitations due to physical health and has a three point Likert scale namely, Yes limited a Lot (YLL), Yes, Limited a Little (YLL), No, Not Limited at All (NNO), weight at 3, 2, 1. Cluster $\mathrm{C}$ role limitations due to emotional problems has a two point Likert scale namely, Yes (Y), No (N), weight at 2, 1. Cluster D measures energy/fatigue and has a six point Likert scale namely, all of the time (AT)), Most of the Time (MT), A Good Bit of the Time (GBT), Some of the Time (ST), A Little of the Time (ALT), None of the Time (NT), and weight at 6, 5, 4, 3, 2, 1. Cluster E which measures emotional well-being has a four point Likert scale namely, All of the time (AT), Most of the Time (MT), Some of the time (ST), A Little of the time (ALT), and weight at 4, 3, 2, 1. Cluster $\mathrm{G}$ which measures social functioning has a four point Likert scale namely, All of the Time (AT), Most of the Time (MT), Some of the Time (ST), A little of the Time (ALT), and weight at $4,3,2,1$. Cluster $\mathrm{H}$ which measures summary of general mental health has a five point Likert scale namely, Definitely True (DT), Mostly True (MT), Don't Know (DK), Mostly False (MF), and Definitely False (DF), and weight at $5,4,3,2,1$.

The Older People's Quality of Life Questionnaire (OPQOL), is a 35- items questionnaire adapted from Bowling (2009). The modified version of the instrument has two sections, A and B. Section A elicited demographic of the respondents. Section B contain on older people quality of life questionnaire. The OPQO has five point likert scales namely, Strongly Agree (SA), Agree (A), Neither agree or Disagree (NAD), Disagree (D), Strongly Disagree (SD), weighted at 5, 4, 3, 2, and 1 respectively. The research instrument was subjected to face validation by three experts, consisting of two experts in Guidance and Counselling, and one in Measurement and Evaluation in University of Nigeria, Nsukka. The reliability of the research instrument was determined through trial testing on 50 older people outside the area of study who were given the instrument to complete. The data collected were then subjected to Cronbach Alpha statistical analysis to determine the internal consistency of the instrument. The analysis result gave alpha coefficient values of 0.75 .

Six hundred and sixty-seven (667) copies of the questionnaire were distributed to the adults by the researchers and collected through self-administration on the spot with the help of research assistants. The data collected were analyzed using mean and standard deviation to answer research question one. The mean benchmark for research question one was 1.0-1.99 for strongly agree, 2.0-2.99 for neither agree nor disagree and 3.0-3.99 for strongly disagree. For research question two and three, coefficient of determination $\left(\mathrm{r}^{2}\right)$ was used. The value of the $\mathrm{r}^{2}$ was interpreted as follows: $0.00-0.20$ (very low extent), $0.21-0.40$ (Low extent), $0.41-0.60$ (moderate extent), $0.61-0.80$ (High extent), 0.81 and above (very high extent). Linear regression was used to test the hypothesis at 0.05 probability level. 


\section{Results}

\subsection{Research Question 1: What is the Attitude to Ageing Among People in Ika South L.G.A.?}

Table 1. Mean responses on the attitude to ageing among people

\begin{tabular}{lllll}
\hline S/N & Statements & $\boldsymbol{X}$ & SD & Dec \\
\hline 1 & As people get older they are better able to cope with life & 1.90 & .53 & SA \\
2 & It is a privilege to grow old & 1.60 & .49 & SA \\
3 & Old age is a time of loneliness & 1.60 & .49 & SA \\
4 & Wisdom comes with age & 1.70 & .45 & SA \\
5 & There are many pleasant things about growing older & 1.79 & .9 & SA \\
6 & Old age is a depressing time of life & 1.89 & .83 & SA \\
7 & It is important to take exercise at any age & 1.49 & .80 & SA \\
8 & As people get older they are better able to cope with life & 1.59 & .80 & SA \\
9 & I find it more difficult to talk about my feelings as I get older & 1.50 & .67 & SA \\
10 & I am more accepting of myself as I have grown older & 1.50 & .67 & SA \\
11 & I don't feel old & 1.60 & .66 & SA \\
12 & I see old age mainly as a time of loss & 1.80 & .60 & SA \\
13 & My identity is not defined by my age & 1.60 & .66 & SA \\
14 & I have more energy now than I expected for my age & 1.50 & .50 & SA \\
15 & I am losing my physical independence as I get older & 1.90 & .70 & SA \\
16 & Problems with my physical health do not hold me back from doing what I want to do & 2.09 & .69 & NAD \\
17 & As I get older I find it more difficult to make new friends & 1.99 & .77 & SA \\
18 & It is important to pass on the benefits of my experience to younger people & 1.99 & .77 & SA \\
19 & I believe my life has made a difference & 2.29 & .78 & NAD \\
20 & I don't feel involved in society now that I am older & 2.29 & .64 & NAD \\
21 & I want to give a good example to younger people & 2.20 & .74 & NAD \\
22 & I feel excluded from things because for my age & 2.10 & .69 & NAD \\
23 & My health is better that I expected for my age & 2.10 & .69 & NAD \\
24 & I keep myself as fit and active as possible by exercising & 1.90 & .72 & SA \\
& Cluster Mean & 1.83 & .21 & SA \\
\hline$K e y s$ & I & &
\end{tabular}

Keys: $X=$ Mean; $S D=$ Standard Deviation; $S A=$ Strongly Agree, $N A D,=$ Neither Agree nor Disagree.

The result presented on Table 1 show that the respondents strongly agreed that as people get older they are better able to cope with life, $(X=1.90, \mathrm{SD}=.53)$ wisdom comes with age $(X=1 / 70, \mathrm{SD}=.45)$, that there are many pleasant things about growing older $(X=1.70, \mathrm{SD}=.45)$, that there are many pleasant things about growing older $(X=1.79, \mathrm{SD}=59)$ and as people get older they are better able to cope with life among others $(X=1.59, \mathrm{SD}=.80)$. The mean responses of these items show that the respondents have positive attitude to ageing. Though, some respondent were indecisive in their attitude to ageing as shown on item $16(X=2.09, \mathrm{SD}=.69), 19(X=2.29, \mathrm{SD}=$ $78), 20(X=2.29, \mathrm{SD}=.64), 21(X=2.20, \mathrm{SD}=74), 22(X=2.10, \mathrm{SD}=69)$ and $23(X=2.10, \mathrm{SD}=69)$, the overall cluster mean of 1.83 with standard deviation of 0.21 indicate that people of Ika South L.G.A. have positive attitude to ageing. 
3.2 Research Question 2: What Extent Does Attitude to Ageing Predict Subjective HealthAmongOlder People in Ika South L.G.A?

Table 2. Regression analysis of extent to which attitude to ageing predict subjective health among older people in Ika South L.G.A.

\begin{tabular}{llll}
\hline Model & $\mathbf{r}^{\mathbf{2}}$ & Standard Error of the Estimate & Decision \\
\hline $\mathbf{1}$ & 0.000 & 0.0982 & Very low extent \\
\hline
\end{tabular}

Theresult in Table 2 showed that to a very low extent, attitude to ageing predicts subjective health among older people given its coefficient of determination $\left(\mathrm{r}^{2}\right)$ value of 0.000 . As result indicated, attitude to ageing accounted for $0.0 \%$ of the variance in subjective among older people in Ika South L.G.A.

3.3 Research Question 3: To What Extent Does Attitude to Ageing Predict Quality of life Among Older People in Ika South L.G.A?

Table 3. Regression analysis on the attitude to ageing predict quality of life among older people in Ika South L.G.A.

\begin{tabular}{llll}
\hline Model & $\mathbf{r}^{2}$ & Standard error & Decision \\
\hline $\mathbf{1}$ & 0.000 & 0.1443 & Very low extent \\
\hline
\end{tabular}

The result in Table 3 showed that to a very low extent, attitude to ageing predicts quality of life among older people given its coefficient of determination $\left(\mathrm{r}^{2}\right)$ value of 0.000 . As result indicated, attitude to ageing accounted for $0.0 \%$ of the variance in quality of life among older people in Ika South L.G.A.

3.4 Hypothesis 1: Attitude to Ageing Is not a Significant Predictor of Quality of Life Among Older People

Table 4.Regression analysis on attitude to ageing on quality of life among older people Ika South L.G.A.

\begin{tabular}{lllllllll}
\hline Model & & B & SE & $\beta$ & T & Sig. & $95 \%$ B CI for B & Decision \\
\hline 1 & (Constant) & 3.600 & 0.049 & & 73.373 & .000 & $3.503,3.696$ & \\
& Attitude to Ageing & .006 & .027 &.-009 & .229 & .819 & $-.058, .046$ & $\mathrm{H}_{01}$ rejected \\
\hline
\end{tabular}

$\mathrm{B}=$ Unstandardized Regression Coefficients, $\mathrm{SE}=$ Standard Error for $\mathrm{B}, \mathrm{b}=$ Standardized regression coefficients, $\mathrm{CI}=$ Confidence Interval.

The result of hypothesis one is shown in Table 4. The result indicated that attitude to ageing is not a significant predictor of quality of life among older people in Ika South L.G.A, $t(655)=-$. 3229, $\mathrm{p}=.819, \mathrm{CI}:-.058, .46$. Therefore, the hypothesis which states that attitude to ageing is not a significant predictor of quality of life among older people was not rejected.

3.5 Hypothesis 2: Attitude to Ageing Is Not a Significant Predictor of Subjective Health Among Older People in Ika South L.G.A

Table 5.Regression analysis on the attitude to ageing as significant predictor of subjective health among older people in Ika South L.G.A.

\begin{tabular}{lllllllll}
\hline Model & & B & SE & $\beta$ & T & Sig. & $95 \%$ B CI for B & Decision \\
\hline 1 & (Constant) & 2.35 & 0.34 & & 69.67 & .000 & $2.279,2.41$ & \\
& Attitude to ageing & .007 & .018 &.-009 & .366 & .714 & $-.29, .043$ & $\mathrm{H}_{02}$ rejected
\end{tabular}

$\mathrm{B}=$ Unstandardized Regression Coefficients, $\mathrm{SE}=$ Standard Error for $\mathrm{B}, \mathrm{b}=$ Standardized regression Coefficients. $\mathrm{CI}=$ Confidence Interval. 
The result of hypothesis two is shown in Table 5. The result indicated that attitude to ageing is not a significant predictor of subjective health among older people in Ika South L.G.A, $t(655)=-.366, p=.714,95 \%$ CI:.-029, .043. Therefore, the hypothesis which states that attitude to ageing is not a significant predictor of subjective health among older people was not rejected.

\section{Discussion}

This research question focused on the attitude to ageing among people of Ika South Local Government Area. The respondents maintained that as people get older they are better able to cope with life, wisdom comes with age, that there are many pleasant things about growing older, and as people get older they are better able to cope with life among others. The mean responses of these items show that the respondents have positive attitude to ageing. Barker, O'Hanlon, McGee, Hicke and Conroy, (2007) reported that ageing was perceived to be associated with negative consequences. Levy and Langer (1994) conducted a comparative study and found that American hearing older adults held the least positive views of the ageing process when compared to American deaf older adults and Chinese older adults. Levy, Hausdorff, Hencke, and Wei (2000) to test memory, hand writing skills and walking ability indicated that subliminal exposure to negative age stereotypes can negatively affect performance in these domains in older adults, while implicit priming with positive stereotypes of ageing (such as wise and sage) tended to improve performance.

The finding showed that attitude to ageing is not a predictor of subjective health among the older people. The result indicated that attitude to ageing accounted for $0.0 \%$ of the variance in subjective health among older people in Ika South L.G.A. Mayer, Baltes, Baltes, Borchelt, Delius, Helmchen, and Wagner (2001) revealed that subjective ratings of health are as relevant for independent living in older people as the objective medical status. Pinquart (2001) opined that subjective health is a significant predictor for depression, hospitalization and mortality in the older people. Beverley (2008) maintained that health is a sensitive variable in relation to the qualitative and quantitative material and social life changes.

In the current study, the result indicated that attitude to ageing is not a significant predictor of quality of life among older people in Ika South L.G.A. This implies that attitude to ageing is not a significant determinant of quality of life among older people. The result indicated that attitude to ageing accounted for $0.0 \%$ of the variance in quality of life among older people in Ika South L.G.A. This implies that attitude to ageing is not a predictor of quality of life. Hooyman and Kiyak (2008) opined that quality of life is the combination of an individual's functional health, feelings of competence, independence in activities of daily living and satisfaction with one's social circumstances. Susniene and Jurkauskas (2009) noted that quality of life is understood as subjective understanding of well-being, taking into account individual needs and understanding. Health factor is often given a priority in quality of life though the quality of life must be understood more widely.

\section{Conclusion}

Based on the findings of the study, the following conclusions were drawn. Older people in Ika South Local Government Area of Delta State maintain positive attitude to ageing; attitude to ageing is not a predictor of subjective health among older people; and attitude to ageing does not significantly predictor quality of life among older people of Ika South. Government and professional guidance counsellors should make use of the information generated from the study to organize workshop training for older people on what constitute subjective health quality of life and what constitute positive attitude to ageing.

\section{Competing Interests Statement}

The authors declare that there are no competing or potential conflicts of interest.

\section{References}

Adesina, O. B. (2011). Managing the Aged in Contemporary African Society: Ogun-State, Nigeria in Perspective. E-Leader Croatia.

Ajzen, I., \& Fishbein, M. (1977). Attitude-behavior relations: A theoretical analysis and review of empirical research. Psychological Bulletin, 84(5), 888.https://doi.org/10.1037/0033-2909.84.5.888

Ajzen, I., \& Fishbein, M. (2005).The influence of attitudes on behavior. The handbook of attitudes, 173(221), 31.

Alberti, K. G. M. M., \& Zimmet, P. F. (1998). Definition, diagnosis and classification of diabetes mellitus and its complications. Part 1: diagnosis and classification of diabetes mellitus. Provisional report of a WHO $\begin{array}{llll}\text { consultation. } & \text { Diabetic } & \text { Medicine, } & \text { 539-553. }\end{array}$ https://doi.org/10.1002/(SICI)1096-9136(199807)15:7<539::AID-DIA668>3.0.CO;2-S 
Amato, K. A. D., Hyland, A., Reed, R., Mahoney, M. C., Marshall, J., Giovino, G., ...\& Nwogu, C. (2015). Tobacco cessation may improve lung cancer patient survival. Journal of Thoracic Oncology, 10(7), 1014-1019. https://doi.org/10.1097/JTO.0000000000000578

Bagdoniene, D. (2002). Gyvenimo Kokybesirgyventojukokybessavokuapibrezimas. Ekonomikairvadyba-2000: aktualijosirmetodologija: tarptautineskonferencijospranesimumedziaga, 46-48.

Barrett, A. E., \& Cantwell, L. E. (2007). Drawing on stereotypes: Using undergraduates' sketches of elders as a teaching tool. Educational Gerontology, 33(4), 327-348. https://doi.org/10.1080/03601270701198950

Coleman, D. A. (2002). Replacement migration, or why everyone is going to have to live in Korea: a fable for our times from the United Nations. Philosophical Transactions of the Royal Society of London. Series B: Biological Sciences, 357(1420), 583-598. https://doi.org/10.1098/rstb.2001.1034

Crano, W. D., \& Prislin, R. (2006). Attitudes and persuasion. Annual Review of Psychology, 57, 345-374. https://doi.org/10.1146/annurev.psych.57.102904.190034

Crick, N. R., \& Dodge, K. A. (1994). A review and reformulation of social information processing mechanisms in children's social adjustment. Psychological Bulletin, 115(1), 74. https://doi.org/10.1037/0033-2909.115.1.74

Cummings, S. M., Kropf, N. P., \& Weaver, K. L. D. (2000). Knowledge of and attitudes toward aging among non-elders: Gender and race differences. Journal of Women \& Aging, 12(1-2), 77-91. https://doi.org/10.1300/J074v12n01_06

Dickel, N., \& Bohner, G. (2012). Minority and majority influence on attitudes. In Psychology-Selected Papers. InTech. https://doi.org/10.5772/36490

Festinger, L. (1957). A theory of cognitive dissonance (Vol. 2). Stanford university press.

Gangbe, M., \& Ducharme, F. (2006). Concepts and models of aging well. Medecine Sciences: M/S, 22(3), 297-300.

Gilgeous, V. (1998). Manufacturing managers: their quality of working life. Integrated Manufacturing Systems, (9), 173-181. https://doi.org/10.1108/09576069810210466

Heeks, R. (Ed.). (2001). Reinventing government in the information age: International practice in IT-enabled public sector reform (Vol. 1). Psychology Press.

Hess, T. M. (2006). Attitudes toward aging and their effects on behavior. In Handbook of the psychology of aging (pp. 379-406). Academic Press. https://doi.org/10.1016/B978-012101264-9/50020-3

Hooyman, N. R., \& Kiyak, H. A. (2008). Social gerontology: A multidisciplinary perspective. Pearson Education.

Juozulynas, A., \& Ceremnych, E. (2005). Gyvenimokokybeirsveikata. Sveikatosmokslai, (1), 71-74.

Kessler, R. C. (1997). The Effects of Stressful Life Events on Depression. Annual Review of Psychology, 48, 191-214. https://doi.org/10.1146/annurev.psych.48.1.191

Kinsella, K. G. (1988). Aging in the third world (No. 79). US Department of Commerce, Bureau of the Census.

Laidlaw, K., Power, M. J., \& Schmidt, S. (2007). The Attitudes to Ageing Questionnaire (AAQ): development and psychometric properties. International Journal of Geriatric Psychiatry: A Journal of the Psychiatry of Late Life and Allied Sciences, 22(4), 367-379. https://doi.org/10.1002/gps.1683

Lloyd-Sherlock, P. (Ed.). (2004). Living longer: Ageing, development and social protection. Zed books.

Morris, B. J. (2007). Climate not Cultivars in the NO-ing of red wines. J Hypertens., 25, 5013. https://doi.org/10.1097/HJH.0b013e328017f70c

Munne, S., Cohen, J., \& Sable, D. (2002). Preimplantation genetic diagnosis for advanced maternal age and other indications. Fertility and Sterility, 78(2), 234- 236. https://doi.org/10.1016/S0015-0282(02)03239-9

Okoye, U. O. (2014). Financial Incentives to Support Family Care-Givers of Older Adults in Nigeria: a Policy Consideration. Research on Humanities and Social Sciences, 4(4), 55-62.

Olukorede, W. E., \& Oluwasegun, A. G. (2014). Socio Demographic indicators of elderly.Economic well-being in Nigeria. Department of Sociology, Lagos state university, Nigeria.

Prislin, R., Shaffer, E., \& Crowder, M. (2012). Populism vs. elitism: Social consensus and social status as bases of attitude certainty. The Journal of social psychology, 152(3), 327-339. https://doi.org/10.1080/00224545.2011.610390 
Ruzevicius, J. (2006). Kokybesvadybosmodeliaiirjutaikymasorganisacijuveiklostobulinimui. Vilnius, Vilniausuniversitetoleidykla.

Schwanen, T., Hardill, I., \& Lucas, S. (2012). Spatialities of ageing: The co- construction and co-evolution of old age and space. Geoforum, 43(6), 1291-1295. https://doi.org/10.1016/j.geoforum.2012.07.002

Susniene, D., \& Jurkauskas, A. (2009). The concept of Quality of Life and Happiness-correlation and differences. Kaunas University of Technology, Panevezys Institute.

Troisi, J. (2004). Ageing in Africa: Older persons as resource. A paper presented at the International Conference on "Rapid Ageing and the Changing role of the elderly in African households", Organized by the Union for African Population Studies UAPS/UEPA (Sengal), the HSRC in collaboration with the Department of Social Development (South Africa) 18-20 August, 2004, Pretoria, South Africa.

Tsakiris, M., Hesse, M. D., Boy, C., Haggard, P., \& Fink, G. R. (2006). Neural signatures of body ownership: a sensory network for bodily self-consciousness. Cerebral Cortex, 17(10), 2235-2244. https://doi.org/10.1093/cercor/bhl131

Wood, W. (2000). Attitude change: Persuasion and social influence. Annual Review of Psychology, 51(1), 539-570. https://doi.org/10.1146/annurev.psych.51.1.539

World Health Organization [WHO]. (2015). World report on ageing and health. Geneva: World Health Organization.

Zhou, X. Q., Zeng, Y. Q., Yang, B. L., \& Wang, A. L. (2007). Effects of health Qigong and Baduanjin on the middle and old aged people's blood lipid. Journal of Beijing Sport University, 30(6), 795-797.

\section{Copyrights}

Copyright for this article is retained by the author(s), with first publication rights granted to the journal.

This is an open-access article distributed under the terms and conditions of the Creative Commons Attribution license (http://creativecommons.org/licenses/by/4.0/). 